\title{
Tree Ordinances as Public Policy and Participation Tools: Development in Alabama
}

\author{
Yaoqi Zhang, Bin Zheng, Brenda Allen, Neil Letson, and Jeff L. Sibley
}

\begin{abstract}
Following a brief overview of the historical evolution of tree ordinances in the United States, this paper focuses on the development of tree ordinances in the state of Alabama to demonstrate how the tree ordinances evolve into law and the role such ordinances have on urban trees. Even though tree ordinances have a long history in the United States, they have been rapidly developing since the 1970s. Among the 100 municipalities that have some type of tree ordinance in Alabama, based on this investigation, the major responsibilities of tree ordinances include: having a tree commission (board), defining tree planting, removal and replacement of trees on public land, public tree protection and care, tree species selection, and dead tree removal on public and private property. Considering the broadness and complexity of urban trees, this paper indicates tree ordinances provide not only a legal framework, but also an effective tool to engage public participation and awareness of urban trees in the process of formulating, implementing, and amending of the tree ordinances. Development of tree ordinances requires government support, citizen participation, and consideration of local resources.

Key Words: Green Law; Landscape Ordinance; Public Attitude; Public Survey; Southeast United States.
\end{abstract}

As a legal framework, tree ordinances are developed to provide authority, offer guidance to residents, and specify the rights, responsibilities and minimum standards to regulate human relationships regarding trees. They also frame and coordinate individual interests concerning trees. Tree ordinances can help society adapt to economic and societal forces in a meaningful way by promoting proper urban forest management.

When utility companies need to remove or trim trees on private lands, what rights do landowners have? When accidents happen, such as damage caused by falling trees, who is responsible? On public land, what are the rights and responsibilities for local government and each citizen concerning trees? Who is the governing authority and management organization for urban forests and what should the budget level be? Tree ordinances are an effective public policy and planning tool to help local governments and policymakers better manage trees.

This paper first introduces the nature of public goods of urban trees, which theoretically justify the importance of tree ordinances to urban forestry. What follows is a brief review of the historical background of tree ordinances in the United States to show practical causes leading to the emergence and development of tree ordinances. Included is an examination of the development of tree ordinances in Alabama based on a collection of tree ordinances. From said examinations, tree ordinances evolve in response to change in each city in providing a legal framework. Meanwhile, the process of developing tree ordinances is an effective tool to engage public and stakeholders' participation, and an important educational tool to raise public awareness of urban trees and the environment.

\section{ROLE OF TREE ORDINANCES FOR SUSTAINING PUBLIC GOODS OF URBAN TREES}

Urban forests are economic goods that provide a variety of benefits. Trees in urban landscapes moderate temperature and microclimates, thereby saving energy (Heisler 1986; Oke 1989;
McPherson 1990). Urban trees can improve air quality (Smith 1981; Nowak and McPherson 1993), help stabilize soils, reduce erosion, improve groundwater recharge, control rainfall runoff and flooding (Sanders 1986), provide animal habitat to sustain biodiversity (Johnson 1988), make neighborhoods more aesthetically appealing, and add to the value of property (Schroeder 1989). Evidence also shows that urban forests may reduce human stress levels (Ulrich 1984), promote social integration of older adults with their neighbors (Kweon et al. 1998), and provide local residents with opportunities for emotional and spiritual fulfillment that help them cultivate a greater attachment to their residential areas (Chenoweth and Gobster 1990). The presence of trees and "nearby nature" in human communities generates numerous psychosocial benefits. Hospital patients were observed to recover more quickly and require fewer painkilling medications when they had a view of nature (Ulrich 1984). Having trees within high-density neighborhoods lowers levels of fear, contributes to less violent and aggressive behavior, encourages better neighbor relationships and better coping skills (Kuo 2003). Office workers with a view of nature are more productive, report fewer illnesses, and have higher job satisfaction (Kaplan 1993).

Urban forests can also be a potential detriment if not wellmanaged and maintained. All trees, no matter how long-lived, eventually decline and die. Therefore, trees impose some risk during their life cycles. Destruction of property, personal injury, and even death can be caused by falling trees. Some trees create potential hazards to the public and risks to the owners (Mortimer and Kane 2004). During and immediately following catastrophic storm events, urban trees are more prone to disruptive results due to clogged streets and accesses, disrupted utility service, damaged property, loss of city services, increased debris removal, increased recovery costs, and a threat to public safety (Letson 2001; USDA Forest Service 2003). In many regions of the U.S., urban trees contribute to the potential of wildfire hazards (Long and Randall 
2004). The risk of wildfire depends on nearby land use, vegetation near homes, and building design and materials. The presence of and spatial configuration of various tree species can also be a concern.

Urban trees have positive and negative impacts on neighborhoods and the surrounding community. Positive impacts include what both tree owners and other citizens can enjoy, negative impacts indicate what citizens may suffer from. Trees are also a type of public good that causes a free rider problem where people obtain the benefits without bearing the costs. There are many potential conflicts involving trees and people within the community. These externalities and conflicts usually result in a call for laws and regulations-such as tree ordinancesas legal provisions adopted by local or community governments.

Since trees in urban settings are part of the landscape and are used for public and private benefit, tree ordinances are often specified in the context of green laws and landscape ordinances. In many states and communities, a tree ordinance is often a component of a landscape ordinance that has been enacted to: 1) establish urban tree management programs, 2) establish new landscape plantings following construction, and 3) preserve existing natural amenities, including historic trees, forest lands, wetlands, and unique habitats. In the western and southern United States, these laws are usually called ordinances with the exception of Florida, where they are referred to as landscape codes. In other parts of the country they are found in sections of zoning ordinances and municipal codes (Abbey 1999), which are a systematically arranged, comprehensive collection of laws.

With other green laws and landscape ordinances, tree ordinances are used as public policies to shape the urban and suburban landscape. Tree ordinances are also a planning tool. Abbey (1998) argued that "laws are now supporting design, and designers are assisting with the establishment of law. Many of such green laws are being written by design professionals." Tree ordinances have been developed to supplement zoning, tree planting, and conservation, especially for new development sites. Tree ordinances are also used to provide a framework for new home builders and public citizens and to delegate responsibility to a public official, such as a director of parks and recreation or a director of public work, for planting and maintaining street trees (Barker 1975). Tree ordinances have been approved or considered as effective policy tools to promote urban trees in the United States (e.g., Davis 1993; Cooper 1996; Schroeder et al. 2003; Galvin and Bleil 2004).

Tree ordinances are usually initiated in response to community motivations as well as political will. Public attitude and preference are important when developing or amending tree ordinances. Usually, as a community grows and expands, population density increases and conflicts rise. Tree ordinances were initially written for protection of public trees, but have gradually moved toward greater regulation. In recent years, serious attention has been given to the importance of municipal liability (Tereshkovich 1990). Many tree ordinances have emerged due to a specific, local issue where there is a conflict between trees, people, or some other interests. For example, off-street parking and vehicle use area (PVA) landscape requirements were a very common "first-generation-limited-use" type of landscape ordinance in many U.S. cities (Abbey 1998). Similarly, Frischenbruder and Pellegrino (2006) uses eight recent case studies to generalize the proposal of using greenways to reclaim nature in Brazilian cities. The following sections will first demonstrate the development of tree ordinances in the United States, then provide further infor- mation using tree ordinances in the state of Alabama as a case study. The conclusion generalizes how to use tree ordinances as a public policy and participation tool to promote urban forestry.

\section{TREE ORDINANCES IN MANY UNITED STATES CITIES}

Legislation has been widely used to protect trees and to develop urban forests for a very long time in Europe (Schmied and Pillmann 2003). In the United States, the earliest tree ordinance was drafted around 1700 by William Penn in order to set standards for tree planting in some of the early settlements around Philadelphia (Zube 1971). This law is also considered as the earliest of all recorded landscape ordinances (Abbey 1999). The Territory of Michigan enacted a law that specified which trees that could be planted on boulevards and squares in the City of Detroit in 1807. In Mississippi, the commission charged with selecting the state's capital city recommended that every other block be filled with native vegetation or be planted with groves of trees in 1821 (Zube 1971).

During the late 18th Century, trees were established in village greens and streets throughout the eastern United States to emulate those found in European cities. By the 1890s, management of public shade trees had clearly become an important part and duty of municipal governance. To address the ambiguous problem between private property and the public right-of-way, "Nail" laws (using nails to distinguish which shade trees were public) were adopted in the New England area to enable towns to take definite steps to distinguish which shade trees were public: Massachusetts in 1890, Connecticut in 1893, Rhode Island and New Hampshire in 1901, Vermont in 1904, and Maine in 1919 (Ricard 2005). Washington D.C. passed a tree ordinance in 1892 to prevent girdling, bricking, wounding, destroying or harming trees in any manner on public or private property or to use them to tie horses. In Maine, the Supreme Court ruled in 1907 that private property such as tress was subject to reasonable regulatory limitations (Durkesen and Richman 1993).

Even though tree ordinances appeared a century ago, only in recent decades have tree ordinances and related green laws become widely adopted in American cities. In 1976, The National Arbor Day Foundation unveiled its Tree City USA recognition program that requires a tree ordinance as one of its four requirements of designated communities. In 2006, there were 3,213 Tree City USA communities, suggesting that an additional number of municipalities have tree ordinances now. Tree ordinances have primarily been used to protect public trees. As of 1984, only one hundred communities nationwide with tree protection laws on private land could be identified (Coughlin et al. 1984). A Michigan State University survey of over 1000 communities reported that $13 \%$ had tree preservation ordinances and restrictions on cutting trees on private property (Kielbaso 1989). In a Missouri survey, $22 \%$ of respondents said they had a "comprehensive tree ordinance" on public property, but only $13 \%$ of respondents stated their communities had a "comprehensive tree ordinance" that defined tree preservation requirements during development (Treiman and Gartner 2004). Since different surveys employed different standards and for various purposes, interpretation of results has varied application. However, it is clear that the United States is currently experiencing a revolution in green laws and tree ordinances that began in the mid-1980s and has continued to increase.

The field of urban forestry as well as tree ordinances is developing hand in hand with urbanization. After World War II, America's 
demographics shifted toward urban areas with more people living in cities than in rural areas for the first time in history. Along with this urbanization was an increase in the amount of developed acres, built space, and impervious surface. Urban sprawl is viewed as a national problem facing American people. A decreasing supply of environmental services is reflected in deteriorated water and air quality as more greenspace is replaced by impervious surface. As discussed earlier, tree ordinances are not just for protecting trees. More importantly, they are often used for regulating relationships among people. In many cases, legal issues and court decisions call for more specific laws regarding tree matters (Merullo and Valentine 1992). The current generation of regulations is increasingly strident and sophisticated (Duerksen and Richman 1993).

Urban forestry and tree ordinances have also evolved with economic development. By the mid-1970s, as Americans were becoming wealthier, urban areas were becoming increasingly crowded. As urban citizens experienced more stress in their daily lives, they began seeking outlets. Dickerson et al. (2001) reported strong community characteristics in educational level, annual per-capita income, average price of home, total population, and poverty level to have a strong relationship with municipal tree ordinances. Education about the ecological, psychological, and economic value of trees and the environment has also promoted the demand for urban trees. The growing demand for urban trees from both public and private land, and a growing number of legal issues engage community motivations and political will to have tree ordinances and to use such as public policy and planning tools for community development.

\section{CASE OF ALABAMA: \\ THE DEVELOPMENT OF TREE ORDINANCES}

Alabama is comparatively a rural state with some representative characteristics for most of the southern United States. The development of tree ordinances in Alabama to some degree can reflect many other states in the south.

Urban trees are an important part of Alabama's history, with tree planting being the most common "community forestry" activity. Currently, Alabama has more than 200 million urban trees, covering $48 \%$ of the urban areas, and $6.3 \%$ of the state (Dwyer et al. 2000). Since Alabama has such a favorable climate for tree growth and abundant forest resources, the presence of trees is sometimes taken for granted. Many of the state's urban trees were planted and have received some level of management. As early as 1763, the British planted live oaks along the streets of Mobile. In the early 1800 s, mulberry trees were planted along the streets of Cahaba, the state's first capital city, and evidence exists of experiments with other tree species as well (Letson 2002). Compared with other states, Alabama has maintained a relatively rural identity longer than most. Therefore, Alabama's urban forest is relatively less-managed even though it has a much better climate for urban trees and does not suffer from the insect and disease pests that devastated large portions of northern and eastern urban forests. Only since the 1960s, as Alabama has become more urban, have city trees become even more important to people.

The Town of Silverhill in Baldwin County, passed the first recorded tree ordinance in 1935, which defined the pruning zone around its street trees. In Mobile County, adjacent to Baldwin County, the City of Mobile, the third largest city in Alabama, was the second city to have a tree ordinance. The original tree or- dinance was passed and the state's first Tree Commission was formed in 1961. The Mobile Tree Commission holds the distinction of being the only one enacted by a state legislative act. Authority was given to the city to protect live oaks in specific areas. Subsequently, Mobile's tree ordinance was included in the "Zoning Ordinance of the City of Mobile" that was first adopted in May 1967, and later amended in April 1992 and November 2005.

Twenty-nine years after the formation of Mobile Tree Commission, Foley became the second Alabama city to create a tree commission, through a local municipal ordinance. Huntsville, the fourth largest city, is also one of the early Alabama cities to have a tree ordinance, adopting its tree management ordinance in $\mathrm{Au}-$ gust 1981. In the 1980s and 1990s a trend developed, spreading tree boards and ordinances across the state (ACES 2002). Tree ordinances and green laws became more and more important to local governments interested in managing Alabama urban forests.

Since tree ordinances can be incorporated with other acts, regulations, and codes, it is often difficult to determine which cities have tree ordinances. The Tree City USA list from the National Arbor Day Foundation, which requires a city to have a tree ordinance for such recognition, has 81 Alabama cities on the list. However, the reality is that some cities do have tree ordinances that are not on the Tree City USA list.

A survey was conducted to collect and assemble comprehensive information regarding tree ordinances in Alabama in 1996, followed by a second survey in 2006 to gain more updated information. Both surveys used similar methodology, which was to identify tree ordinances in all cities and towns in Alabama. Letters were sent to each municipal clerk or mayor requesting information regarding landscape or tree ordinances, or city codes regulating trees if they did not have landscape or tree ordinances. Meanwhile, there was a search for tree ordinances on city websites. In cases when the survey did not receive a response, there was an e-mail follow-up with phone calls, and a second letter. A total of 300 surveys were sent to the most populated cities and towns. Since Alabama is comparatively a rural state, all cities and towns with more than or close to 1000 people were contacted. The study received approximately 130 responses in each of the two surveys: some respondents sent their tree or landscape ordinances or website addresses while others simply replied that they did not have an ordinance.

Since there were not many cities that had tree ordinances, the two surveys were combined with the information collected from other sources. It was determined that 83 municipalities have some type of tree or landscape ordinance addressing matters related to trees. In about 20 cities, the City Code contains at least some regulations specifically dealing with trees, landscape and zoning ordinances, city beautification, and other parameters. Only approximately 20 cities have self-contained and well-developed tree ordinances or landscape regulations (meaning the ordinance is independent rather than included in the city code). These cities include Abbeville, Ashville, Auburn, Decatur, Dothan, Eufaula, Fairhope, Florence, Gulf Shores, Helena, Hoover, Huntsville, Mobile, Moundville, Opelika, Red Bay, Tuscumbia, and others.

After reviewing and examining the tree ordinances collected in Alabama, a summary of the major components was created (Table 1). From the compilation, the top six issues addressed were: 1) having a tree commission or board, 2) tree planting, removal and replacement on public land, 3) public trees protection and care; 4) tree species selection recommended to be planted, 
5) dead or deceased tree removal on private property, and 6) definition of street trees. Except for Mobile and Huntsville, all other cities have developed their tree ordinances after 1985.

Table 1: Major issues addressed by tree ordinances in Alabama cities.

\begin{tabular}{lc}
\hline Issues Addressed & \# of cities \\
\hline Amended at least once & 13 \\
Having tree commission (board) & 73 \\
Tree planting, removal and replacement on public land & 70 \\
Public trees protection and care & 68 \\
Tree species selection recommended to be planted & 57 \\
Dead or deceased tree removal on private property & 51 \\
Definition of street trees & 34 \\
Nuisance trees & 32 \\
Private trees protection & 32 \\
Spatial requirement (e.g., distance from curb, sidewalk, & 31 \\
$\quad$ street corners and fireplugs, distance between trees) & 27 \\
Penalty for violation & 20 \\
Arborists licensed and bonded & 19 \\
Tree topping, pruning and corner clearance & 12 \\
Tree removal and protection on development sites & 9 \\
Tree preservation and planting credit & 5 \\
Heritage trees & 1 \\
Tree protection close to or under utilities line &
\end{tabular}

Data sources: Authors' compilation from surveys conducted in 1996 and 2006. The data set included 81 cities.

\section{TREE ORDINANCES AS PUBLIC POLICY AND PARTICIPATION TOOLS}

Almost all Alabama cities regulating trees have city tree commissions (or tree boards) that take the responsibilities of initiating and amending the tree ordinances (Table 1). In Alabama, tree ordinances have most often started following the establishment of a city tree commission (board). Tree commissions play an important role in engaging public participation technically and politically. For example, the first tree ordinance in Montgomery (the capital of Alabama) was passed in 1984. Montgomery formed a five-member tree commission filled exclusively by city personnel to allow the city to meet one of the Tree City USA standards. In 2001, local citizens formed the Montgomery Tree Committee (MTC). The group's intent was to create an informally structured urban tree advocacy group that would promote a municipal urban forestry program. The MTC wrote a project proposal for the City of Montgomery to develop a comprehensive urban forestry plan. The proposal was approved by the U.S. Forest Service and awarded funds to implement the plan in 2002. With the committee's efforts, the City of Montgomery hired its first urban forester in 2004. In September 2005, Montgomery passed an ordinance providing minimum landscape requirements for off-street parking. The MTC, incorporated as a nonprofit membership organization and in 2006, was recognized as a nonprofit 501(c)(3) corporation by the Internal Revenue Service. The MTC began working with the City of Montgomery to merge ordinances and tree regulations to create a comprehensive and functional tree ordinance in November 2007. The revised ordinance gave the urban forester and the municipal government policies, guidelines, and authority needed to manage trees on public property.

Tree ordinance development involves various stakeholders, particularly builders, utility companies, and new home owners. For example, Huntsville, the fourth largest city in Alabama, adopted its tree ordinance in August 1981. Huntsville's tree ordinance primarily addressed right-of-way trees and responsibility for their care, causing some conflicts among the utility companies, the owners of right-of-way trees, and the City. At the time, the development of the tree ordinance proved to be a complicated process. According to former City Forester Chuck Weber (1982), Huntsville passed another landscape ordinance "Zoning Ordinance of the City of Huntsville, Alabama" in 1989 which included Article 71, "Off-Street Parking and Vehicle Use Area (PVA) Landscaping Requirements." The essential purpose of this ordinance was to improve the visual appearance of PVA while preserving trees and other landscape elements so as to protect streams and watercourses from excessive runoff.

In February of 2004, Huntsville's City Council adopted a complete revision of the city's standards for tree work, paying more attention to forest management and education than regulation. Negotiations took place for over two years before the Tree Commission arrived at wording which all parties could agree. The more challenging issue was related with power-line clearances. Huntsville has a long growing season and tremendous species diversity, but these assets mean either severe line-clearance pruning or frequent re-pruning of fast-growing trees. The compromise that broke the logjam was to increase the clearance distance around

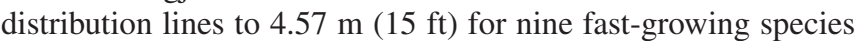
(hackberry/sugarberry, box elder, silver maple, tree-of-heaven, cottonwood, princess tree, Siberian elm, black cherry, and loblolly pine), while leaving the clearance for other species at $3 \mathrm{~m}(10 \mathrm{ft})$.

The new tree ordinance in Huntsville reflects compromise and collaboration between utility companies, city government, and individuals. While the utility companies had an obligation to provide safe and reliable utility service to its customers, some trees were topped and became unsightly. The city and utility company worked out a solution to completely remove old, poorly trimmed trees, and replant them with new ones on private property. The new tree ordinance required utility companies to cut and remove trees at their expense, the city to take responsibility for planting new trees, with private households responsible for tree maintenance.

In the City of Auburn, the tree commission, developers, and builders worked together in an attempt to keep mature trees on private property. For every large tree retained, the developer or builder receives credit for two to three trees. The Auburn landscape ordinance is targeted at developers and is designed to encourage the planting and retention of larger growing, long-lived tree species and to discourage problem species such as "Bradford" pears and crapemyrtles.

Tree ordinances are also an important tool in planning and coordinating within governmental agencies and being consistent with other codes and regulation. For example, Mobile's tree ordinances are included in several places such as the Zoning Ordinance of the City of Mobile, Subdivision Regulations for the City of Mobile, and The Land Use Administration Section of Urban Development. The Mobile Planning Commission requires a buffer planting strip or a wooden privacy fence of $1.83 \mathrm{~m}(6 \mathrm{ft})$ in height.

In Auburn, the city's tree and green ordinances are mostly defined in the Auburn Landscape Regulations and the Auburn Zoning Ordinance of 2006. Proposals made by the Auburn Tree Commission go to the City Planning Committee which refines and adapts them prior to referral to the Auburn City Council for approval. The City appointed an urban forester in charge of city trees and provides "Best Practices" to developers and pri- 
vate citizens. In the Auburn Zoning Ordinance, the most related components are land use classification, requirement of open space, buffer-yard, plant materials, and minimum plant size.

Public support is critical for the approval and implementation of tree ordinances. According to a survey report (Zhang et al. 2007), over $85 \%$ of the respondents would support their local government developing tree ordinances imposing guidelines on builders and developers regarding trees on new construction sites. The survey indicated that about $75 \%$ of the public would support a local tree ordinance imposed on public property, with less support for tree ordinances to govern trees on private property. The survey results imply that before passing a tree ordinance to govern trees on private property, a careful and well planned communication plan must be developed to gain public support. This is not surprising since the "taking issue" of private property rights has been a big concern across the United States. Tree and land ordinances face similar "taking issue" challenges (Durkesen and Richman 1993). As population increases and land development expands, trees on private property must be included in tree ordinances. Cooper (1996) demonstrated a successful example of using tree ordinances to protect and replace trees on private lands.

\section{CONCLUSION}

Tree ordinances emerge and evolve in response to urban, societal, and economic changes. Just as other laws and regulations target specific issues, tree ordinances are governing policies for urban tree management. In the United States and in Alabama more specifically, regulations on public land are more developed and have received more public support compared with private land management. Tree ordinances are gradually evolving to address emerging issues of growth and conflict. Several cities in Alabama have amended their tree ordinances due to meet these dynamics. When situations change and new conflicts emerge, a tree ordinance should be amended. For example, it was primarily in conflicts among utilities companies and owners of right-of-way trees in the City of Huntsville that led to the change of the city tree ordinances. Tree ordinances are specifically designed as public policy and planning tools for individual municipalities and must meet local needs (Miller 1997). From this aspect, we anticipate the integration of tree ordinances with environmental protection (e.g., riparian buffer) and new developments will become more important.

Unlike many laws and regulations, tree ordinances are more successful when they include public participation and citizen leadership. Financial support from federal and local government and private sources often play a critical role in helping nongovernment organizations and citizens effectively participate. For example, city tree commissions are usually established through the public taking responsibility for developing and amending tree ordinances in the U.S., and especially in the Alabama. At the same time, developing tree ordinances is a great opportunity to engage public participation, solve local issues through negotiation and compromise, and create a policy that works for the community.

More importantly, tree ordinance implementation and compliance is largely dependent on public participation considering many tree ordinances contain regulations that are voluntary, difficult to monitor, and effectively enforce. Citizens should be strongly encouraged to participate in administration of tree ordinances with decision-making authority, or in an advisory role. Nichols (2007) suggests citizen bodies such as tree com- missions, vegetation committees, tree review boards, urban forestry advisory boards, environmental commissions, and planning commissions must be involved. A wide public participation can not only help address the issues of the stakeholders of a city, but also provide an education tool for the public about tree ordinances, with eventual help in implementation.

\section{LITERATURE CITED}

Abbey, D.G.B. 1998. U.S. Landscape Ordinances: An Annotated Reference Handbook. John Wiley \& Sons, Inc., New York.

Abbey, D.G.B. 1999. Green Laws, Building Landscapes in the Twentyfirst Century, in Proceedings 1999 ASLA annual meeting, American Society of Landscape Architects, Washington D.C.

ACES (Alabama Cooperative Extension System). 2002. Urban and community Forestry: Alabama's Five-Year Strategic Plan. ANR-1220, Alabama Cooperative Extension System, AL.

Barker, P.A. 1975. Ordinance control of street trees. Journal of Arboriculture. 1:212-216.

Chenoweth, R.E., and P.H. Gobster. 1990. The nature and ecology of aesthetic experiences in the landscape. Landscape Journal 9: 1-18.

Cooper, J.C. 1996. Legislation to protect and replace trees on private land: Ordinances in Westchester county, New York. Journal of Arboriculture 22:270-278.

Coughlin, R.E., D.C. Mendes, and A.L. Strong. 1984. Private Trees and Public Interest: Programs for Protecting and Planting Trees in Metropolitan Areas. Research Report Series No. 10, Univ. of Pennsylvania Department of City and Regional and City Planning, University of Penn., Philadelphia., PA. 158 pp.

Davis, R.L. 1993. Street tree trends in Kansas and the influence of community factors. Journal of Arboriculture 19:201- 208.

Dickerson, S.D., J.W. Groninger, and J.C. Mangun. 2001. Influences of community characteristics on municipal tree ordinances in Illinois, U.S. Journal of Arboriculture 27:318-325.

Duerksen, C.J., S. Richman. 1993. Tree Conservation Ordinances, American Planning Association, Planning Advisory Service Report \# 446, Chicago.

Dwyer, J.F., D.J. Nowak, M.H. Noble, S.M. Sisinni. 2000. Connecting people with ecosystems in the 21st century: an assessment of our nation's urban forests. Gen. Tech. Rep. PNW-GTR-490. U.S. Department of Agriculture, Forest Service, PNRS. Portland, OR.

Frischenbruder, M.T.M., and P. Pellegrino. 2006. Using greenways to reclaim nature in Brazilian cities. Landscape and Urban Planning 76: $67-78$.

Galvin, M.F., and D. Bleil. 2004. Relationship among tree canopy quality, community demographics, and tree city program participation in Maryland, U.S. Journal of Arboriculture 30:321-327.

Heisler, G.M. 1986. Effects of individual trees on the solar radiation climate of small buildings. Urban Ecology 9:337-359.

Johnson, C.W. 1988. Planning for avian wildlife in urbanizing areas in America desert/mountain valley environments. Landscape and Urban Planning 16:245-252.

Kaplan, R. 1993. The role of nature in the context of the workplace. Landscape and Urban Planning 26 (1-4):193-201.

Kielbaso, J.J. 1989. City Tree Car Program: A Status Report. In G. Moll and S. Ebenreck, Shading Our Cities. Island Press, Washington, D.C.

Kuo, F.E. 2003. The role of arboriculture in a healthy social ecology. Journal of Arboriculture 29:148-155. 
Kweon, B.S., and W.C. Sullivan, A.R. Wiley. 1998. Green common spaces and the social integration of inner-city older adults. Environment and Behavior 30(6):832-858.

Letson, N. 2001. Making Our Urban Forests Safer. ANR-1210, Alabama Cooperative Extension System, Auburn, AL.

Letson, N. 2002. Urban \& Community Forestry: Alabama's Five-Year Strategic Plan. Alabama Cooperative Extension System, ANR-1220, Auburn, AL.

Long, A., and C.K. Randall. 2004. Wildfires risk assessment guide for homeowners in the Southern United States. School of Forest Resources and Conservation, University of Florida, Gainesville.

McPherson, E.G. 1990. Modeling residential landscape water and energy use to evaluate water conservation policies. Landscape Journal 9:122-134.

Merullo, V.J., and M.D. Valentine. 1992. Arboriculture and the Law. International Society of Arboriculture, Champaign, IL. 110 pp.

Miller, R.W. 1997. Urban Forestry: Planning and managing urban greenspaces. Prentice Hall, New Jersey.

Mortimer, M., and B. Kane, 2004. Hazard tree liability in the United States: uncertain risks for owners and professionals. Urban Forestry and Urban Greening 2:159-165.

Nichols, S.S. 2007. Urban Tree Conservation: a White Paper on Local Ordinance Approaches. Montgomery Tree Committee. Montgomery, Alabama.

Nowak, D.J., and E.W. McPherson. 1993. Quantifying the impact of trees: the Chicago Urban Forest Climate Project. Unasylva 173(44): $39-44$.

Oke, T.R. 1989. The micrometeorology of the urban forest. Philosophical Transactions of the Royal Society of London 324(Series B):335-349.

Ricard, R.M. 2005. Shade Trees and Tree Wardens: Revising the History of Urban Forestry. Journal of Forestry 107 (July/August):230-233.

Sanders, R.A., 1986. Urban vegetation impacts on the hydrology of Dayton, Ohio. Urban Ecology 9:361-376.

Schmied, A., and W. Pillmann. 2003. Tree protection legislation in European cities. Urban Forestry and Urban Greening 2:115-124.

Schroeder, H.W. 1989. Environment, behavior and design research on urban forests. In E.H. Zube \& G.T. Moore (Eds.), Advances in Environment, Behavior and Design (pp. 87-117). New York: Plenum.

Schroeder, H.W., T.L. Green, and T.J. Howe. 2003. Community tree programs in Illinois, U.S.: a statewide survey and assessment. Journal of Arboriculture. 29(4): 218-225.

Smith, W.H. 1981. Air pollution and forests. Springer, New York.

Tereshkovich, G. 1990. Texas municipal tree and landscape ordinances. Journal of Arboriculture 16:62-65.

Treiman, T., and J. Gartner. 2004. Community forestry in Missouri, U.S.: Attitudes and Knowledge of local officials. Journal of Arboriculture 30(4):243-250.
Ulrich, R.S. 1984. View through a window may influence recovery from surgery. Science 224:420-421.

USDA Forest Service. 2003. Urban Tree Risk Management: A Community Guide to Program Design and Implementation. NA-TP-03-03, USDA Forest Service NE Area, St. Paul, MN.

Weber, C.C. 1982. A Tree Management Ordinance for Huntsville, Alabama. Journal of Arboriculture 8:81-82.

Zhang, Y., A. Hussian, J. Deng, and N. Letson. 2007. Public Attitudes Toward Urban Trees and Supporting Urban Tree Programs. Environment and Behavior 39:797-814.

Zube, E. 1971. Trees in Woodlands in the Design of the Urban Environment. In Trees and Forest in an Urbanizing Environment. Planning Residential Development Service No. 17. The University of Massachusetts Press, Amherst, Massachusetts. pp. 145-150.

Acknowledgments. This study was financially supported by the Alabama Urban and Community Forestry Assistance program, and National Urban and Community Forestry Advisory Council Competitive Program. During our survey and interviews, we have received great support from many cities' urban foresters and clerks who sent us the tree and landscape ordinances and answered many specific questions.

Yaoqi Zhang (Corresponding Author)

School of Forestry and Wildlife Sciences

Auburn University

Auburn, AL 36849, U.S.

Yaoqi.Zhang@auburn.edu

Bin Zheng

School of Forestry and Wildlife Sciences

Auburn University

Auburn, AL 36849, U.S.

Brenda Allen

School of Forestry and Wildlife Sciences

Auburn University

Auburn, AL 36849-5418, U.S.

Neil Letson

Alabama Cooperative Extension System

P.O. Box 302550

Montgomery, AL 36130-2550, U.S.

Jeff L. Sibley

Department of Horticulture

Auburn University

Auburn, AL 36849-5418, U.S. 
Résumé. À partir d'une brève revue de l'évolution historique des arrêtés sur les arbres aux États-Unis, cet article met l'accent sur l'évolution des arrêtés dans l'état d'Alabama afin de démontrer comment les arrêtés sur les arbres ont évolué vers une législation et le rôle que ces arrêtés ont sur les arbres urbains. Même si ces arrêtés sur les arbres ont une longue histoire aux États-Unis, ils se sont rapidement développés dans les années '70. Parmi les 100 municipalités qui ont certains types d'arrêtés en Alabama, les sujets majeures de ces arrêtés sur les arbres incluent, et ce en se basant sur cette enquête: présence d'une commission de l'arbre, définition de la plantation d'arbres, abattage et remplacement des arbres sur le territoire public, protection et entretien des arbres publics, sélection des espèces d'arbres, abattage des arbres morts sur propriétés publique et privée. Du fait de la complexité et de l'étendue des arbres urbains, cet article fait mention que les arrêtés sur les arbres fournissent non seulement un cadre légal, mais qu'ils sont aussi un outil efficace pour favoriser la participation et la conscientisation publique dans le processus de formulation, d'implantation et d'amendement des arrêtés sur les arbres. Le développement de ces arrêtés sur les arbres requièrent le support du gouvernement, la participation des citoyens et la prise en compte des ressources locales.

Zusammenfassung. Ein kurzer Überblick über die historische Entwicklung von Baumschutzsatzungen in den Vereinigten Staaten. Dieser Artikel fokussiert auf die Entwicklung von Baumschutzsatzungen im Staat Alabama, um zu demonstrieren, wie sich Baumschutzsatzungen im Recht entwickeln und welche Rolle solche Satzungen für die betroffenen Bäume haben. Obwohl Baumschutzsatzungen eine lange Geschichte in den Vereinigten Staaten haben, fand seit den 70ger Jahren eine rasche Entwicklung statt. Unter 100 Kommunen in Alabama, die eine Form von Baumschutzsatzung haben, schließen die Hauptaufgaben dieser Satzungen, basierend auf dieser Untersuchung, folgendes ein: es gibt einen Baumausschuss, es gibt Vorschriften zur Pflanzung, Fällung und Ersatzpflanzung von Bäumen auf öffentlichem Grund, öffentlicher Baumschutz und Baumpflege, Baumartenauswahl und Totholzbeseitigung auf öffentlichem und privatem Grund. In Anbetracht der Breite und Komplexität von urbanem Baumbestand, zeigt dieser Artikel, dass Baumschutzsatzungen nicht nur ein legales Regelwerk liefern, sondern auch ein effektives Werkzeug sind, um die Öffentlichkeit auf den Prozess von Entwicklung, Festsetzung und Durchsetzung solcher Baumschutzsatzungen aufmerksam zu machen und daran zu beteiligen. Die Entwicklung von Baumschutzsatzungen erfordert Unterstützung der Landesregierung, Teilnahme der Bevölkerung und einen Einbezug von lokalen Ressourcen.

Resumen. Siguiendo un breve repaso de la evolución histórica de las ordenanzas de árboles en los Estados Unidos, este reporte se enfoca al desarrollo de ordenanzas de los árboles en el Estado de Alabama para demostrar cómo las ordenanzas de árboles evolucionan en leyes y el rol que tales ordenanzas tienen en los árboles urbanos. Aunque las ordenanzas de árboles tienen una larga historia en los Estados Unidos, se han desarrollado más rápidamente desde los 1970s. Entre 100 municipalidades que tiene algún tipo de ordenanza en Alabama, con base en esta investigación, las principales responsabilidades de las ordenanzas de árboles incluyen: una comisión del árbol, definición de plantación de árboles, remoción y remplazo en áreas públicas y propiedades privadas. Considerando la amplitud y complejidad de los árboles urbanos, este reporte indica que las ordenanzas de árboles proveen no solamente una estructura legal, sino también una herramienta efectiva para lograr la participación pública y la conciencia de los árboles urbanos en el proceso de formulación, implementación y mejoramiento de las ordenanzas. El desarrollo de las ordenanzas de árboles requiere soporte gubernamental, participación ciudadana y consideración de recursos locales. 